\title{
Editorial
}

\section{Highly Purified Insulins}

\author{
K. G. M. M. Alberti and M. Nattrass
}

More than a quarter of a century ago Harfenist and Craig [1] showed that commercial insulins contained several impurities. Clinical awareness of this as a potential problem stems more, however, from the observation in 1966 of Mirsky and Kawamura [2] using disc gel electrophoresis that crystalline insulin contained 6 to 10 different components. This report was closely followed by the classic study of Steiner and his colleagues [3], in which they described three peaks, the $\mathrm{a}, \mathrm{b}$ and $\mathrm{c}$-components, on gel filtration chromatography of conventional bovine crystalline insulin. Subsequent work has shown that the c-peak contains desamidoinsulins, arginine insulin and ethylester insulin, as well as the true Sanger insulin, all these proteins having a molecular weight of approx. 6000 . The b-component comprises proinsulin, intermediates and insulin dimer while the a-component consists of a heterogeneous mixture of proteins with molecular weights of greater than 12000 . This demonstration of the impurity of pharmaceutical insulin preparations led to the development by Schlichtkrull and colleagues [5] of the first of the highly-purified porcine insulins (the original MC or monocomponent insulin) which was chromatographically and electrophoretically pure, while single component insulin which was chromatographically pure was described in 1972 [6]. These highly purified insulins have now been available for nearly 8 years and it is perhaps pertinent to summarize the benefits that have accrued from their use as well as place in perspective some of the more extravagant claims that have been made on their behalf.

Most attention has been paid to the relative lack of antigenicity of the new insulins. Berson et al in 1956 [7] were the first to show the presence of, and realise the significance of, anti-insulin antibodies in insulin-treated diabetics. Deckert [8] then reported that circulating insulin antibodies could be demon- strated in $97 \%$ of insulin-treated patients, while none were found in normal subjects or diabetics who had not been given insulin. It was initially thought that this antigenicity was due to the structural differences between bovine and human insulin, or to abnormal metabolism of insulin in diabetics. However, it was subsequently shown that injection of homologous insulin into pigs or humans still resulted in antibody formation although to a lesser degree $[9,10,11]$. It has since been shown that although bovine preparations are certainly more antigenic than porcine and human insulins the remaining antigenicity is due to impurities in the insulin preparation with the a-component being particularly antigenic and antibodies to proinsulin and insulin derivatives also being formed. Piquancy has been added to the argument by the discovery of Bloom and his colleagues [12] that patients treated with conventional insulins, or what they emotively call "dirty insulins", have significant antibody titres against other pancreatic hormones such as pancreatic polypeptide and VIP.

Many studies have now been performed of antibody levels in patients treated with conventional insulins compared with patients treated only with highly purified insulins. Similarly antibody levels have been followed in patients changed from conventional bovine or bovine/porcine insulins to the highly purified insulins $[13,14,15,16,17,18,19,20,21]$. In the early days of the new insulins they were said to be virtually non-immunogenic although more recent findings have been less dramatic $[18,19]$. Certainly, however, when patients are changed from the older to the highly purified insulin there is a decrease in antibody titre $[13,14,16,22]$ and a fall in total insulin requirement $[13,23]$. Asplin et al [21] in a large series of patients showed not only a fall in serum bound insulin but a simultaneous rise in serum free insulin. Others have suggested that the fall in insulin 
requirement occurs only in those subjects with initial high requirements and high serum total insulin binding capacity [24]. In one of the more recent studies, Bruni and his colleagues [20] in this journal have reported that patients treated only with highly purified insulins for 5 years or more developed no antibodies to proinsulin, while 2 out of 13 developed a-component antibodies. In conventionally treated patients antibodies to both a-component and proinsulin were found in more than half the patients.

A few patients show an early and catastrophic fall in insulin requirement on changing from old to new insulins [25], with Asplin et al [21] showing this in $21 \%$ of patients. This occurs prior to any change in antibody characteristics and may be due to a difference in the way in which antibodies in these individuals bind bovine and porcine insulins. This can be predicted by differential binding studies prior to changeover. More usual is a gradual decrease in insulin requirement of $20-30 \%$ over the course of 3 to 12 months [13]. Clinically it is probably wise to decrease the total insulin dose by 20 to $30 \%$ on changeover and then adjust according to response.

These observations are interesting but do not indicate whether it is actually beneficial for the patient to be treated with a less antigenic insulin. Are the anti-insulin antidodies harmful? In the "honeymoon" period of the highly purified insulins it was said that insulin antibodies caused immune complex disease [26] and could be implicated in the long-term complications of diabetes. This has not been substantiated; there is indeed no evidence to suggest that complications found in insulin-treated diabetics are not identical with those found in some patients who have never been trated with insulin. In the occasional patient with massive insulin resistance due to a very high antibody titre it is probably beneficial to change to highly purified insulins when requirements will fall but this is a rare event with the more pure, although not highly-purified, insulins that have been available for the last twenty years. It has also been suggested that insulin antibodies may cross the placenta and be harmful to the foetus of the diabetic mother [26a].

The main argument about insulin antibodies centres on what effect they have on the control of diabetes. This problem is still unresolved. Dixon and his colleagues [27] and Fankhauser [28] suggested that the presence of insulin antibodies improved diabetic control by providing a buffer against sudden changes in free insulin concentration. This has not been substantiated. Others have suggested that changing patients to highly purified insulins with a consequent decrease in antibody titre improves control of blood glucose $[14,21,29]$. In none of these studies, however, have proper control groups been included. This is of particular importance in this type of study in that patients are automatically cared for more thoroughly when taking part in this type of trial. In one of the few studies where adequate numbers of samples were taken and an equivalent degree of care given before and after the change in insulin therapy no change in control could be discerned although the number of patients studied was small, and only patients with unstable diabetes were studied [18].

In normal subjects insulin is secreted in sharp peaks in response to meals, and the aim of diabetic therapy should be to mimic this. Heding and her colleagues have shown well the sluggish response of free insulin concentrations to therapy in patients who have anti-insulin antibodies [30]. It is thus theoretically likely that patients with no or low antibodies will have a more desirable free insulin pattern. The fact that this still remains unproven probably reflects more our inability to mimic adequately the physiological response with subcutaneous insulin therapy than any failing on the part of the new highly purified insulins. In making a realistic assessment, however, of the proven harm of antibodies and the real benefits to the patients of the new insulins one must leave a question mark beside their effects on blood glucose control in the diabetic.

Despite the lack of evidence concerning control there are some real advantages to the new insulins and, equally, some suggestive disadvantages to the old insulins. Insulin allergy has been known since the introduction of insulin therapy, with red patches and intense irritation at the injection site. Already in 1949 Jorpes [31] had shown that using insulin which had been recrystallized several times lessened this local response. More generalised allergic reactions are also decreased by changing to highly purified insulins $[32,33]$ although a report has now appeared of a patient allergic even to the new insulin [34]. Another complication of insulin therapy has been the appearence of patches of lipoatrophy at the most commonly used injection sites. These are not harmful although one cannot but ponder on whether absorption is normal from such abnormal tissue. Many reports have appeared of the filling in of these patches if highly purified insulins are injected into the hollows [35] although the impact of this is lessened by the report that use of conventional insulin in the same way can equally well effect a cure [36]. On the other hand, lipoatrophy appears to be less common in general in patients treated only with the new insulins [37].

The arguments against the old insulins are more indirect. Obviously many patients have been treated 
with the conventional insulins without detriment. Equally it could be said that most insulin-treated diabetics are troubled by either longterm or shortterm complications of either the disease or of therapy. Whether these will be lessened by the new insulins remains to be proven although a trial seems worthwhile. We also do not know what dangers are inherent in the use of impure insulin preparations apart from antibody formation. The finding of antibodies against VIP and pancreatic polypeptide is also of interest, but again is of totally unproven pathological significance. It seems reasonable, however, to suggest that it is more logical to use a pure than an impure drug even without definitive proof of benefit.

What of the cost? Highly purified insulins are more expensive to produce, and therefore to use; there are increased production losses; and until very recently only porcine highly purified insulins have been available. Production losses are now within acceptable limits and both this and the increased cost are offset by the decrease in requirement by individual patients. There is some concern about the supply of pigs, however; although this problem may be bypassed if a wider selection of highly purified bovine insulins becomes available. Again these new bovine insulin preparations need full and rigorous testing in view of the inherent greater immunogenicity of bovine compared with porcine insulin.

What then do we conclude? Should we uniformly transfer all patients to highly purified insulins? At present we cannot answer with an unqualified yes. Certainly there are groups of patients where there are strong indications for the use of the new insulins. These include patients with insulin allergy, either local or generalised; patients with lipoatrophy; patients with insulin resistance which could perhaps now be redefined as those taking more than 100 units/day [38]; and patients with short-term insulin requirements, such as non-insulin dependent diabetics undergoing surgery, non-diabetics under intensive care and gestational diabetics. For the rest, it is certainly not unreasonable to use the new insulins, and we indeed use them widely, but we must remain aware that definitive proof about their benefits, with particular regard to control and complications, is still lacking. Use of phrases such as "dirty insulin" is of value only if it stimulates further work, and may indeed be retrogressive if it gains appeal purely as a superficial catch phrase. Facts must override emotions! The length of time required for a properly conducted trial to produce the appropriate proof may well deter many investigators. However, such proof is vital and the time factor unimportant. As Arnold Schoenberg replied when told that his Violin Concerto required a soloist with six fingers: "Very well, I can wait".

\section{References}

1. Harfenist, E. J., Craig, L. C.: Counter current distribution studies with insulin. J. Am. Chem. Soc. 74, 3083-3087 (1952)

2. Mirsky, I. A., Kawamura, K.: Heterogeneity of crystalline insulin. Endocrinology 78, 1115-1119 (1966)

3. Steiner, D. F., Hallund, O., Rubenstein, A., Cho, S., Bayliss, C.: Isolation and properties of proinsulin, intermediate forms, and other minor components from crystalline bovine insulin. Diabetes 17, 725-736 (1968)

4. Schlichtkrull, J., Ege, H., Jørgensen, K. H., Markussen, J., Sundby, F.: Die Chemie des Insulins. In: L. Mohr, R. Staehelin (Eds.): Handbuch der Inneren Medizin, Vol. $2 \mathrm{~A}$, pp. 77-127. Berlin, Heidelberg, New York: Springer 1975

5. Schlichtkrull, J., Brange, J., Ege, H., Hallund, O., Heding, L. G., Jørgensen, K., Markussen, J., Stahnke, J., Sundby, F., Vølund, A.: Proinsulin and related peptides. Diabetologia 6, $80(1970)$

6. Root, M. A., Chance, R. E., Galloway, J. A.: Immunogenicity of insulin. Diabetes 21 (Suppl. 2) 657-660 (1972)

7. Berson, S. A., Yalow, R. S., Bauman, A., Rothschild, M. A., Newerly, K.: Insulin-I 131 metabolism in human subjects: Demonstration of insulin-binding globulin in the curculation of insulin trated subjects. J. Clin. Invest. 35, 170-190 (1956)

8. Deckert, T.: Insulin antibodies. Copenhagen: Munksgaard 1964

9. Brunfeldt, K., Deckert, T.: Antibodies in the pig against pig insuin. Acta Endocrinol. (Kbh.) 47, 367-370 (1964)

10. Deckert, T., Grunddahl, E.: The antigenicity of pig insulin. Diabetologia 6, 15-20 (1970)

11. Deckert, T., Andersen, O. O., Grunddahl, E., Kerp, L.: Isoimmunization of man by recrystallized human insulin. Diabetologia 8, 358-361 (1972)

12. Bloom, S. R., Adrian, T.E., Mitchell, S.J., Barnes, A. J., Kohner, E. M.: Dirty insulin: a stimulant to autoimmunity. Diabetologia 12, 381 (1976)

13. Andreani, D.: Some aspects of treatment with monocomponent (MC) and monospecies (MS) insulins. Excerpta Medica Int. Congr. Ser, 316, 68-75 (1973)

14. Lavaux, J. P., Ooms, H. A., Christiansen, A. H.: Insulin antibodies in insulin-treated patients; a clinical trial with highly purified insulins. Excerpta Medica Int. Congr. Ser. 316, 40-46 (1973)

15. Schlichtkrull, J., Brange, J., Christiansen, A. H., Hallund, O., Heding, L. G., Jørgensen, K. H. Munkgaard Rasmussen, S., Sørensen, E., Vølund, A.: Monocomponent insulin and its clinical implications. Horm. Metab. Res. 5 (Suppl.), 134-143 (1974)

16. Bruni, B., D’Alberto, M., Osenda, M., Ricci, C., Turco, G. L.: Clinical trial with monocomponent lente insulins. Diabetologia 9, 492-498 (1973)

17. Czyzyk, A., Lawecki, J., Rogala, H., Miedzinska, E., PopikHankiewic, A.: Serum levels of insulin-binding antibodies in diabetic patients treated with monocomponent insulin. Diabetologia 10, 233-236 (1974)

18. Yue, D. K., Turtle, J. R.: Antigenicity of "monocomponent" pork insulin in diabetic subjects. Diabetes 24, 625-632 (1975)

19. Devlin, J. G., Parameswaran, V.: Immunologic response to mono-component insulin in newly diagnosed diabetic patients. J. Ir. Med. Assoc. 68, 301-305 (1975)

20. Kurtz, A. B., Mustaffa, B. E., Daggett, P. R., Nabarro, J.D. N.: Effect of insulin antibodies on free and total plasma insulin. Lancet 1977 II, 56-58

21. Asplin, C. M., Hartog, M., Goldie, D. J.: Change of insulin dosage, circulating free and bound insulin and insulin antibodies on transferring diabetics from conventional to highly purified porcine insulin. Diabetologia 14, 99-105 (1978) 
22. Mirouze, J., Orsetti, A., Schmouker, Y., Carty, E., Almes, N.: Diabète sucré. Son traitement par les insulins purifées monocomposées. Nouv. Presse Med. 2, 1981-1985 (1973)

23. Oakley, N. W.: Effect of "fractional" insulins on total plasma insulin binding capacity and insulin requirement in severe diabetes. Lancet 1976 I, 994-996

24. Mustaffa, B. E., Daggett, P. R., Nabarro, J. D. N.: Insulin binding capacity in patients changed from conventional to highly purified insulins. An indication of likely response. Diabetologia 13, 311-315 (1977)

25. Logie, A.W., Stowers, J. M.: Hazards of monocomponent insulin. Br. Med. J. 1976 I, 879-880

26. Wehner, H., Huber, H., Kronenberg, K. H.: The glomerular basement membrane of the rabbit kidney on long-term treatment with heterologous insulin preparations of different purity. Diabetologia 9, 255-263 (1973)

26a. Persson, B.: Treatment of diabetic pregnancy. Isr. J. Med. Sci. 11, 609-616 (1975)

27. Dixon, K., Exon, P. D., Malins, J. M.: Insulin antibodies and the control of diabetes. Q. J. Med. 176, 543-553 (1975)

28. Fankhauser, E.; Neuere Aspekte der Insulintherapie. Schweiz. Med. Wochenschr. 99, 414-420 (1969)

29. Lithner, F.: Treatment of diabetes mellitus with monocomponent insulins. A preliminary report. Opuscula Medica 20, 249-254 (1975)

30. Munkgaard Rasmussen, S., Heding, L. G., Parbst, E., Vølund, A.: Serum IRI in insulin-treated diabetics during a 24-hour period. Diabetologia 11, 151-158 (1975)
31. Jorpes, J. E.: Recrystallized insulin for diabetic patients with insulin allergy. Arch. Intern. Med. 83, 363-371 (1949)

32. Teuscher, A.: The place of the "monocomponent" insulins in the therapy of diabetes mellitus. Schweiz. Med. Wochenschr. 105, 485-494 (1975)

33. Korp. W., Levett, R. E.: Experiences with monocomponent insulin. Wien. Klin. Wochenschr. 85, 326-330 (1973)

34. Reisner, C., Moul, D. J., Cudworth, A.: Generalised urticaria preciptated by a change to highly purified insulins. (in press)

35. Teuscher, A.: Treatment of insulin lipoatrophy with monocomponent insulin. Diabetologia 10, 211-214 (1974)

36. Hulst, S. G. Th.: Treatment of insulin-induced lipoatrophy. Diabetes 25, 1052-1054 (1976)

37. Deckert, T., Andersen, O. O., Poulsen, J. E.: The clinical significance of highly purified pig-insulin preparations. Diabetologia 10, 703-708 (1974)

38. Tattersall, R. B.: Highly purified insulins. Prescribers' Journal 18, 8-13 (1978)

Prof. K. G. M. M. Alberti

Dr. M. Nattrass

Chemical Pathology and Human Metabolism

Level D

South Laboratory and Pathology Block

General Hospital

Southampton S09 4XY

England 